\title{
From Time to Time
}

\section{Auto-Affection in Derrida's 1964-65 Heidegger Course}

\section{Tracy Colony}

Journal of French and Francophone Philosophy - Revue de la philosophie française et de langue française, Vol XXVII, No 1 (2019) pp 14-33

\author{
Vol XXVII, No 1 (2019) \\ ISSN 1936-6280 (print) \\ ISSN 2155-1162 (online) \\ DOI $10.5195 /$ jffp. 2019.876 \\ www.jffp.org
}

\section{(oc) $\mathrm{EY-NC-ND}$}

This work is licensed under a Creative Commons Attribution-Noncommercial-No Derivative Works 3.0 United States License.

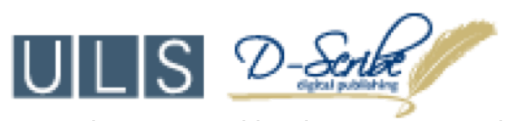

This journal is operated by the University Library System of the University of Pittsburgh as part of its D-Scribe Digital Publishing Program, and is co-sponsored by the University of Pittsburgh Press 


\title{
From Time to Time
}

\section{Auto-Affection in Derrida's 1964-65 Heidegger Course}

\author{
Tracy Colony \\ Bard College Berlin
}

L'énigme est toujours celle de la temporalisation... ${ }^{1}$

Derrida always stressed the importance of his engagement with Heidegger and often returned throughout his life to different aspects of Heidegger's thought. ${ }^{2}$ With the recent publication of his 1964-65 course, Heidegger: The Question of Being and History ${ }^{3}$ greater insight is now possible into the exact terms of Derrida's early engagement with Heidegger and the significance he would accord it in the seminal works of 1967 and beyond. ${ }^{4}$ It is well known that Derrida was familiar with Heidegger from the beginning and references to Heidegger appear in his first publications. Derrida's early treatment of Heidegger in the courses he gave at the Sorbonne from 1960-64 and such texts as "Violence and Metaphysics" first published in 1964 all indicate Heidegger's clear and increasing importance in this period. ${ }^{5}$ However, the appearance of Derrida's 1964-65 course makes possible for the first time an appreciation of the intricate and singular dynamics of this encounter. After four years teaching as an assistant at the Sorbonne, this was the first course that Derrida delivered in his new position at the École normale supérieure. Meeting every other week from November 1964 to late March 1965 Derrida's course is comprised of nine sessions. The publication of this course is based upon the material Derrida prepared in the form of detailed lecture notes which have been exactingly edited and masterfully translated. With the reception of this work just beginning, many directions of questioning are being unfolded. ${ }^{6}$ However, one aspect not yet addressed in this early reception which will be crucial for approaching and orienting this text is the theme of auto-affection.

The concept of auto-affection is important for assessing Derrida's Heidegger course for two reasons. Firstly, Derrida understands auto-affection 
to be Heidegger's most radical figuration of temporality in the period of Being and Time. Secondly, tracing Derrida's early focus on auto-affection in Heidegger can provide an important context for understanding the initial development of what would become a prominent theme in Derrida's own work. ${ }^{7}$ Derrida's understanding of auto-affection as the most original configuration of temporality in Heidegger's thought during the composition of Being and Time and also a concept that was key in his movement beyond fundamental ontology is initially curious in that the term auto-affection [Selbstaffektion] does not appear in Being and Time. For Derrida, the importance of this term in the period of Being and Time derives from the understanding of temporality that Heidegger arrived at in the context of his reading of Kant. The text which is the basis for Derrida's account of Heidegger's understanding of temporality as auto-affection is his 1929 book Kant and the Problem of Metaphysics. ${ }^{8}$

Derrida's emphasis on Heidegger's Kantbuch, which he will describe in 1968 as a book that "envelops" ${ }^{\prime \prime}$ Being and Time, is based on the fact Heidegger's reading of Kant was to constitute the first division of the second part of Being and Time. However, Derrida also points to the fact that the material for Heidegger's Kantbuch was presented in a lecture course immediately preceding Being and Time: "the essential content of this book was presented in lectures in 1925-26 - and so not long before the writing of Sein und Zeit." ${ }^{10}$ In a translator's note Geoffrey Bennington corrects Derrida's dates pointing to the fact that Heidegger referred instead to his 1927-28 lecture course on Kant as the first elaboration of what was essential in the Kantbuch. However, Derrida is also correct in that although it was only published in German in 1976, Heidegger's 1925-26 lecture course Logic: The Question of Truth $^{11}$ contains over one hundred pages devoted to a phenomenological reading of time in Kant's Critique of Pure Reason which culminates in an interpretation of time as "original pure self-affection."12 Moreover, the argument and focus of these pages exactly prefigures those in the later lecture course and the Kantbuch. In 1968 Derrida would again refer to this early lecture course as foreshadowing the Kantbuch which he describes as: "A result of the lectures given in 1925-26, it was also to correspond, in its content, with the second, unpublished part of Sein und Zeit."13 While Heidegger's engagements with Kant chronologically frame the project of Being and Time, for Derrida, the importance of this context derives firstly from Heidegger's insights regarding the auto-affection of temporality that arose in this encounter. ${ }^{14}$

Derrida first refers to the "auto-affection of time by itself"15 in Session 7 of his course. The context for this reference is the description of resoluteness [Entschlossenheit] and authenticity [Eigentlichkeit] as dissimulating a more original passivity in Dasein, the signification of which Heidegger had already "recognized at the outset."16 Earlier than the metaphysics of subjectivity still present in the themes of Entschlossenheit and Eigentlichkeit, Derrida finds in 
Heidegger's understanding of the auto-affection of time a more radical figure of passivity and finitude at the heart of existence. This figure of auto-affection which opens exactly within temporalization and which Derrida understands as obfuscated by Heidegger's privileging of ethico-metaphysical senses of the future, death and freedom, is also seen by Derrida as what would open the way for Heidegger's turn beyond the residual elements of a free subject in Being and Time. The point in Derrida's reading where auto-affection is drawn together with Being and Time is Heidegger's concept of Sichüberlieferung which Derrida translates as "auto-tradition" and articulates as: "a complementary concept or, if you prefer, the other side of the concept of pure auto-affection that describes time in Kant and the Problem of Metaphysics. And if we could do so, this is the book we would need to delve into here. Auto-affection and autotradition - such is the movement of the temporalization of time."17 The examination of Derrida's understanding of this composition can shed considerable light not only on Derrida's engagement with Being and Time but also on the development of his own thought. My argumentation in this essay is structured in three sections.

In the first section, I present a brief introduction to Derrida's course in terms of the theme of temporality. This theme can be seen as a principal motif through which Derrida traces the way in which Being and Time both points beyond, and yet, ultimately remains within the epoch of metaphysics that it brings to light. In the second section, I then draw out Derrida's treatment of the auto-affection of time in this course. While many accounts of Derrida's early relation to Heidegger have focused on the ontological difference, the significance that Derrida accorded Heidegger's repetition [Wiederholung] of Kant on the auto-affection of time has gone relatively unnoticed. The new material which this course provides can help elaborate this important aspect of Derrida's early Heidegger reception. In the final section, I conclude with a suggestion for better understanding Derrida's references to Heidegger on the auto-affection of time in his 1967 work Voice and Phenomenon.

\section{I.}

Derrida opens his course by describing the reasons behind his decision to entitle it "Heidegger: The Question of Being and History." While many contemporary readings of Being and Time in this early stage of its French reception were content to simply present it as a work of phenomenology in the service of ontology, Derrida's title explicitly announces a move beyond this common framing. Rather than a work of ontology, Derrida will unfold his reading of Being and Time within the dimension of the question of being that it more originally provokes. Although the term ontology is still functioning in a positive sense in Being and Time and its questioning is guided by the thematics of a fundamental ontology, Derrida stresses that this is not its ultimate scope. Rather than just the uncovering of a more original sense of ontology, what Heidegger is carrying out in this work is a destruction of the 
history of ontology that is also a destruction of ontology itself. One of the remarkable virtues of Derrida's early reception of Being and Time is that he reads it continually in relation to Heidegger's later works and approaches it not as an incomplete or abandoned project, but rather, unfolds it in relation to the questionability of being that it evokes and that articulated the need to pass beyond its own initial formulations. The guiding role that Derrida accords the question of the truth of being is the basis from which he interprets the significance of such crucial terms as destruction, ontology and perhaps most importantly for this course, history itself.

In Session 2 Derrida poses the central question: "How then do matters stand between the question of being and history?"18 After tracing Heidegger's announced departure from a prosaic sense of historicity which would attempt to explain the origin of beings by simply referring to another being, Derrida articulates a more original relatedness between the question of being and history. However, Derrida is very clear that the historicity of the truth of being itself is not explicitly raised within the scope of Being and Time and that it examines only the historicity of Dasein. In Being and Time the historicity of being itself must first pass through the question of the historicity of Dasein. Derrida describes this sense of historicity which remains within a hermeneutic of Dasein in terms of two "assurances." These two assurances which Heidegger accords himself in posing the question of being, and which bring to light the historical character of that question, are both given in the form of an always already [toujours déjà]. This relatedness to a past forms the common root of both assurances and marks the implicit historicity of the question of being which then must be made explicit through the analytic of Dasein.

The first of these assurances is that the meaning of being is always already in a sense available to Dasein. Dasein already finds itself within a preunderstanding of the meaning of being. This familiarity with being, within which Dasein already moves and which provides an initial orientation for questioning, is taken by Heidegger as a fact [Faktum]. This first assurance is understood as the fact of language in that the meaning of the word is (to be) in any language is of necessity already understood. This ontological understanding already implicit and assumed in language is also tied to history in that there is no language without history. The second assurance with respect to posing the question of being is the projection of an absolute proximity of Dasein to the meaning of being. The privileged example of a being from which to pose the question of being is taken to be Dasein in its ability to question: "Nothing is closer to the question than the being that is questioning." ${ }^{19}$ However, for Derrida, this absolute proximity of the character of Dasein as a questioning being to the meaning of being itself is also based upon Dasein's proximity to itself.

This other figure of proximity is announced in Heidegger's description of Dasein as: "This being, which we ourselves in each case are and which 
includes inquiry among the possibilities of its being [...]." ${ }^{20}$ For Derrida: "This is where the second assurance is taken out. This is what I will call the Faktum of the we are." 21 This figure of proximity does not designate any already determined group or predicates, but rather, only articulates Dasein in terms of its proximity to the question of the meaning of being. In being close to the question of being we are close to what we ourselves are. This logic of proximity which will also structure Heidegger's many later invocations of nearness [Nähe] will be one of the most important points of engagement in Derrida's reception and deconstruction of Heidegger's thought. After the presentation of the historicity implied in the two assurances, Derrida then turns to the way in which this theme of historicity is located within the architectonics of Being and Time.

The topic of historicity appears in two places in Being and Time. First, it is cursorily announced in $\$ 6$ of the Introduction and then treated more extensively in Chapter 5 of Division 2 entitled: "Temporality and Historicality." For Derrida, this configuration represents the fact that within the methodological ordering of Being and Time: "The problem of historicity is grafted onto that of temporality." 22 This figuration of the relation between historicity and temporality in terms of a graft [greffe] is explicitly deployed by Derrida to indicate firstly that historicity is not simply the same as temporality. However, historicity is also something that, although different, can only be understood in terms of its rootedness in the movement of temporality. This rootedness of history in Dasein's temporality is already announced in $\S 6$ of the Introduction where temporality is described as the condition of possibility for historicity. For Derrida, this grafting of history onto temporality renders historicity simply a mode of temporality which is modified and modalized merely in terms of the structures of temporalization itself. This is not to say that historicity demands to be conceived as purely independent from the temporality of Dasein which would in effect invite the resurgence of the most prosaic metaphysics. Rather, what is lacking are original concepts which could both articulate their relatedness, and yet, still distinguish historicity from Dasein's temporality.

The danger Derrida finds in grafting history onto the temporality of Dasein is that what is rooted loses its ability to differentiate itself from the root and becomes simply indistinguishable from the movement of temporality: "There is here an irreducible elementary structural nucleus within which the movement of the Geschehen appears to be isomorphic with the movement of temporality." 23 This absorption of history into temporality and the absence of new concepts for articulating history beyond this temporal ground are the reasons for Derrida's account of a certain "running out of breath" [essoufflement] in the final sections of Being and Time. This theme of running out of breath is one that Derrida refers to throughout his course to describe the ending of Being and Time that was both the encountering of a limit and the articulation of a need to turn beyond its projected structure. ${ }^{24}$ These two 
reasons are then traced to a common source which is the understanding of time as the transcendental horizon for approaching both the meanings of history and being. This privileging of time as the fundamental hermeneutic clue for posing the question of being was a presupposition which held the project of Being and Time firmly in the grasp of metaphysics. However, Derrida also clearly articulates ways in which Heidegger's early phenomenology of temporality can be seen to differentiate itself from the traditional metaphysics of presence which extended from Plato to Husserl. The basis for this advance is Heidegger's understanding of temporality beyond the logic of absolute presence, and rather, as a figure of ecstasis.

One of the most important themes through which Derrida traces Heidegger's departure from traditional metaphysics, most often exemplified in this course by Husserl, is the meaning accorded to the present: "Everything - everything: that is, not only this or that gesture of the destruction of Metaphysics but the totality of the destruction and the meaning that directs it as a whole - everything is played out around the meaning of the Present." 25 For Derrida, Husserl remains a metaphysician of presence in that the present is the unquestioned ground of identity, philosophical meaning and the ultimate foundation for the movement of temporality. The dimensionality of time is thought on the basis of the pure presence of the present to itself. The future is thought as a coming future present and the past as a past present. In Heidegger, Derrida finds the articulation of a more original extension [Erstreckung] of temporality. Instead of reducing the extendedness of life from birth to death in an absolute present, Heidegger thinks presence itself as determined from out of this more original ecstasis. Dasein's relatedness to birth and death are exactly constitutive of Dasein: "Dasein is its past and is its future, is its birth and its death. But the is [est] here designates a Being that can absolutely not have the form of presence or phenomenality." 26 While Derrida unfolds the implications of Heidegger's shift in thinking ecstasis and not presence as the fundamental origin of temporality, there remains within Heidegger's privileging of the future a residual form of metaphysics that, despite its advances, rendered Being and Time fundamentally continuous with that tradition.

The ultimate source of temporality which opens the ecstatic structure of Dasein is the indeterminate character of death. Rather than a contingent event which would at some point become present, Derrida reads this indeterminacy of death as opening the ecstasis of the future from out of which the present itself is configured. This rethinking of presence as determined by the ecstatic horizon of the future is described by Derrida as constituting: "the present as the past of a future." ${ }^{27}$ This expression, which Derrida often repeats, may not be taken in any chronological sense as merely indicating the ordering of the present behind a not yet present future. Rather, it points to a more original complicity of past and future in the determination of presence. However, within this relation, the ecstasis of the future is clearly privileged to such a 
degree that Derrida simply says that Heidegger: "substitutes - as he always does in Sein und Zeit - the privileging of the future for that of the present." 28 Rather than thinking the present as the ground for the movement of temporalization, Derrida reads in Heidegger: "the future as presentifying itself as temporalization of temporality." ${ }^{29}$ In this shift to think the present from out of the ecstasy of the future Derrida finds Heidegger "illegitimately privileging here the ekstasis of the future - and this is consistent with the privileging of Entschlossenheit and the finite horizon of death." ${ }^{30}$ However, it is at this point, where temporality in Being and Time is enclosed within this privileging of the future, and all its attending pathos of resolution, that Derrida will first introduce the theme of the auto-affection of time.

Derrida introduces the auto-affection of time almost as an unexpressed resource located just behind the explicit contours of Being and Time. Referring back to auto-affection from the edges of Being and Time brings into relief the limits of that text via a passivity in Dasein that is more original than the "metaphysics of proper (eigentlich) subjectivity" ${ }^{31}$ still present in the structure of resoluteness.

[I]t is a certain irreducible passivity of ek-sistence and $D a$ sein. Passivity, nucleus of passivity, which must not be understood on the model of thingly intra-worldliness or as sensibility, but at the very least as auto-affection of time by itself. Now it is this originary passivity that Entschlossenheit runs the risk of dissimulating and, having recognized at the outset the signification of this passivity of being in history (comprehended in history) or of being in the world, Heidegger was bound to seek further than Eigentlichkeit and Entschlossenheit. ${ }^{32}$

Derrida will then immediately clarify Eigentlichkeit as "proper, i.e., close to oneself" 33 so that the logic of proximity which has guaranteed the hermeneutic privilege of Dasein is also brought into question through the passivity announced by the auto-affection of time. I turn now to draw out the way in which Derrida can be seen to read Being and Time against the background of what he considered to be Heidegger's more original understanding of temporality in the thought of auto-affection.

\section{II.}

Derrida's first reference to an originary sense of affectivity underlying the concepts of authenticity, being-towards-death and anxiety comes in Session 6 where, referring to these central themes, he laments his course will have to skip over many sections of Being and Time but that:

We should especially have to give back their true meaning to the analyses of world and time and wrest them from the mist of romantic pathos in which they have been 
enveloped. I say "enveloped," as with a rich coat that would hide the skeletal body of a philosophical intention, whereas if pathos there be - and there is - it hangs on an ontological re-understanding of affectivity, which is no longer being understood by way of metaphysics as an accident of sensibility foreign to reason, and so on. ${ }^{34}$

This true meaning of the world and time, understood in terms of an affectivity interpreted beyond its traditional determinations, can be seen as a reference to Heidegger's treatment of the auto-affection of time in Kant and the Problem of Metaphysics. In this text Heidegger charts the way in which Kant's Critique of Pure Reason points toward a more original sense of time than what was explicitly presented in the transcendental aesthetic. This more original sense, which is brought to light via Heidegger's own phenomenologically clarified temporality, defines the fundamental structure of transcendence in the Kantian subject. Heidegger's reading also uncovers the most extreme index of finitude at the center of this temporality in what he describes as "taking-instride" [Hinnehmen].

Time as a form of intuition does not create what it intuits, but rather, must take-in-stride and receive what gives itself. However, the pure form of intuition is different in that: "Pure intuition, in the taking-in-stride, gives itself that which is capable of being taken in stride." ${ }^{35}$ Although it is beyond the scope of this essay to present Heidegger's account of auto-affection in his Kantbuch, I will briefly focus on this figure of taking-in-stride because it looks forward to the sense of passivity in Derrida's reading. This sense of taking-instride is for Heidegger both formative and receptive. Formative in the sense that it gives a possible pre-view or image to time and also receptive in that for pure intuition what it intuits is time itself. This giving form to time is understood to be the operation of the transcendental imagination; however, this is not simply a static transcendental form, but rather, it too is characterized by a receptive relation to its own intuition of time. This figure of passivity and finitude is the basis for Heidegger's description of autoaffection at the heart of time: "Pure taking-in-stride, however, means: becoming affected in the absence of experience, i.e., self-affecting. Time as pure self-affection is that finite, pure intuition which bears and makes possible in general the pure concept (the understanding) that stands in essential service to intuition. The idea of pure self-affection [...] determines the innermost essence of transcendence." ${ }^{36}$ In pure intuition, time itself is constituted by its passive reception of itself. This sense of affection is not an event that a transcendental subject would simply undergo, but rather, what first makes possible the synthesis of time into a specific horizon or form. This original differing within the pure auto-affection of time, that opens the possibility of the temporalization of time, announces the radical sense of passivity that Derrida will develop in his course. ${ }^{37}$ 
The concept in Being and Time that Derrida reads in relation to the autoaffection of time is Sichüberlieferung which he translates as "auto-tradition." In spite of Heidegger's consistent reduction of history to temporality, the one concept which Derrida finds that somewhat indicates a new vocabulary for historicity is Sichüberlieferung. This term describes the originary synthesis of temporality that first opens the possibility of historicity: "This Sichüberlieferung, this passage from self to self that constitutes the nuclear synthesis of historicity and is, properly speaking, the first tissue, the first text [...]." ${ }^{38}$ The sense of auto-transmission in this term may not be understood at the level of any intra-temporal or merely empirical meaning, but rather, must be seen as the synthesis that first opens the possibility of historicity as such. Earlier than either remembering or forgetting, the synthesis that makes possible this passage from self to self must already be in place. Strictly speaking, the movement of temporalization which makes possible the handing down of an authentically repeated possibility is itself earlier than the self or autos which would seem to preceed it. However, the most important aspect of this synthesis of past and present from out of the ecstasy of the future is its deeper character as auto-affection. This other side of auto-tradition opens an earlier difference within this seemingly original continuity of ecstatic temporality. The difference which opens within the pure auto-affection of time is seen to determine this movement of temporalization and draw into question its status as an apparently discreet and unitary medium for selfrelation.

As a synthesis of Dasein's ecstatic temporality, the auto-transmission of a past possibility projected from out of Dasein's futurity initially seems to be enclosed within Entschlossenheit understood as the attribute of a free subject: "This first tissue, this first text is authentically historical only if it is constituted, I would almost say written on the basis of an Entschlossenheit, a resolute anticipation and a freedom for death." 39 However, Derrida also stresses that Entschlossenheit may not be simply defined within the horizon of morality or psychology. Prior to the ethico-metaphysical resolution of a free subject Derrida also describes an earlier auto-traditionality of Entschlossenheit itself as the primary condition of authentic historicity. And yet, the way Derrida brings together auto-affection and Sichüberlieferung will exactly draw into question the meaning of auto-tradition as a movement which would simply supervene upon an already given unity of self. What is properly at issue is the very continuity of the passage from self to self in auto-tradition which Derrida describes as the first tissue or text. While this autotransmission of self to self is described as the first tissue, because it is made possible by a movement of temporal synthesis which is itself more originally determined by auto-affection, it cannot be understood as an originally homogeneous medium. Earlier than the seemingly original continuity of this first text is the constitutive difference within the pure auto-affection of time. 
Derrida clearly understands the figure of auto-affection as the more original term in the relation between auto-affection and auto-tradition: "time, precisely, of which auto-affection is the name." 40 This priority is expressed in different ways throughout his course. Initially, he describes Sichüberlieferung as a "complementary concept" 41 of the pure auto-affection of time and as "the other side [l'autre face] of the concept of pure auto-affection." ${ }^{42}$ Sichüberlieferung is then later described as "another name for the auto-affection of pure time" 43 and as "the general structure of temporality as auto-affection." ${ }^{44}$ Although Derrida draws together both of these terms: "Auto-affection and autotradition - such is the movement of the temporalization of time." ${ }^{45}$ it is the constitutive role that Derrida accords the aspect of differing within the autoaffection of time that is the basis for this priority. In Heidegger's repetition of Kant the auto-affection of time is seen to uncover an instance of difference within the temporalization of time that is constitutive of both prosaic presence and ecstatic temporality. This difference which Derrida finds in Heidegger's thought of auto-affection is key for articulating Derrida's understanding of the way in which Heidegger diverges from Husserl's account of temporalization. Whereas Derrida will repeatedly describe Heidegger's thought as ultimately "analogous" 46 to Husserl in terms of substituting the present with the future, and presence with ecstasis, this determination is never applied to the figure of auto-affection.

On Derrida's reading of Heidegger's repetition of Kant, the auto-affection of time is not the reception of an already given being that is external to a subject. Nor is it, as in Kant's account of the phenomenalization of a being that I have not created, an intuitus derivativus. It is not the affection of a subject by any empirical externality because, strictly speaking, time is neither something outside nor a being. This reception does not transpire within an already thematized temporal form or subjectivity, but rather, is a figure of differing that opens the possibility of the temporalization of time itself. This earlier alterity opens the possibility of the synthesis of temporality whether understood on the basis of the present or from out of the ecstasy of Dasein's future. As pure auto-affection the movement of temporalization is first opened by the otherness of time to itself. Derrida describes auto-affection as a concept that is "as incomprehensible as is, in truth, the movement of temporalization." 47 This enigma which does not simply befall any more original unity of self is a differing which first opens and remains constitutive of all thematizations of self-relation. It is perhaps from this perspective that Derrida allows the auto-affection of time to envelop the whole of Being and Time and point beyond it.

For Derrida, the thought of auto-affection is able to articulate the earliest ecstatic structure of Dasein's transcendence. Auto-affection thus defines time as the transcendental horizon for the question of being and also, simultaneously, indicated a way beyond the lingering metaphysics of subjectivity which also still determined that horizon: "You know that this 
theme of pure auto-affection is merely the opening in Heidegger's thought to the theme of the transcendence of Dasein and to the question of being, beyond the metaphysics of subjectivity." 48 Affectivity is seen to figure the transcendence of Dasein and, as such, open beyond any traditional thematization of subjectivity. At this point Derrida explicitly contrasts Heidegger's sense of affectivity as transcendence with the contemporaneous treatment of this theme in Michel Henry's The Essence of Manifestation which appeared in $1963 .{ }^{49}$ In this work there is also an appeal to an originary sense of affection. For Henry, all previous phenomenological accounts of manifestation in terms of intentionality or ecstatic temporality had overlooked an earlier moment of transcendental affectivity in which there is ultimately no division between what appears and the one to whom it appears. Rather than moving beyond subjectivity, as in Derrida's reading of autoaffection in Heidegger, there is in Henry an equation of affectivity with pure subjectivity and pure self-coincidence which he thought was merely dissimulated in the previous phenomenologies of Husserl and Heidegger. This is perhaps the reason for Derrida's, rather undissimulated, description of Henry's book as: "totally pointless in its result."

Derrida's contrast between Henry's appeal to "affectivity as pure subjectivity, without transcendence outside itself" ${ }^{\prime 51}$ and Heidegger's sense of affection which opens beyond the metaphysics of subjectivity is instructive. In contrast to Henry's supposed uncovering of a pure subjectivity, the figure of auto-affection in Heidegger is more radical in that it can be seen to think the auto not as an original unity, but as itself constituted by an earlier division and differing. This sense of constitutive deferral within auto-affection can be seen as what Derrida describes as the deeper character or "other side" of Sichüberlieferung in Being and Time. This position of auto-affection as the other side of auto-tradition is announced as the most immediate reason for his "detour" through Heidegger's repetition of Kant. Referring to the Kantbuch Derrida presents the following passage in both French and then the original German:

According to its essence, time is pure affection of itself. Furthermore, it is precisely what in general forms seeing which, setting off from itself, heads for something like the "from-out-itself-toward-there ...," so that the upon-which looks back and into the previously named toward-there. ${ }^{52}$

In this quotation Heidegger is describing originary time from which the derivative thematization of time as a sequence of nows arises and then relates back to. Stressing the ecstatic figuration of this departure, which however still remains a conservation of self, Derrida immediately comments on this quotation: "Well, this exiting from self that rebounds onto self and holds itself in the exit from self, gives itself and transmits itself so as to keep it, its own ekstatic movement, in itself, and that is auto-transmission [...]." ${ }^{53}$ Derrida 
clearly emphasizes that the form of this self-keeping is not grounded in the present, but rather, must be understood as an ecstatic figure of repose.

Derrida's reading of auto-transmission is not to be understood as the handing down of any specific ontic content from self to self, but rather, as the "pure, a priori, non-empirical" 54 condition of the possibility of traditionality as such. This movement of auto-tradition is not the transmission of possibilities within an already constituted subject, but instead, the most originary synthesis of ecstatic temporality that opens the possibility of historicity itself. Derrida is very explicit that this transmission of self to self is not held in a present but is thought on the basis of temporality as an ecstatic movement. However, this ecstatic repose of the self is a continuity that is opened by a still more original division within time itself. Derrida indicates the scope of this difference within pure auto-affection as the other side of auto-tradition at the opening of the final session: "The notion of Sichüberlieferung which at least in name presented itself as original, referred us to the theme of time as the other [temps comme l'autre], pure affection [...]." ${ }^{55}$ This sense of alterity within the relation of time to itself, is not simply an interval between thematized units of time, but rather, an earlier difference that first makes these articulations possible. Earlier than any apparently original continuity of a temporal medium, whether as the self-presence of the present or ecstatic temporality opened and unified from out of Dasein's future, this seemingly pure continuity is opened by a more radical dis-continuity. This figure of difference within auto-affection is returned to in the final moments of the course and read beyond the orders of history and being itself.

Derrida's final reference to auto-affection comes at the very conclusion of his course when he steps back from the question of historicity within Being and Time and poses the wider question of the historicity of being as such. The thought of auto-affection has already been articulated as crucial for Heidegger's turn from historicity grafted onto the temporality of Dasein to the history of being itself. This final reference to auto-affection is presented in terms of the destruction of both history and being. Beyond the horizon of Being and Time, these terms are rethought as metaphors which are undergoing destruction: "the signification history is also, like that of Being, a metaphor to be destroyed." 56 This sense of metaphor is not simply a rhetorical trope but describes an interminable condition of displacement in relation to the proper as the truth of being. This destruction is not a philosophical gesture because the question of being as history has itself been brought about by the destruction of philosophy.

The sense of destruction which history and being are undergoing is described as a destruction which overflows these very terms: "It is accomplished slowly, patiently, it patiently takes hold of the whole of language, of science, of the human, of the world. And this patience is not even ours, it is not an ethical virtue. It is the auto-affection of what one can no longer even call being." 57 With this image of history and being as metaphors 
being destroyed Derrida returns to his initial elaboration of the title which guided his course. Both of these destructions are described as generating another metaphor, that of the future itself behind which is the opening of the question itself which he then describes as difference. These depictions can perhaps shed some light on Derrida's later account of the incessant necessity of passing through the erased determination of the ontological difference and the truth of being. ${ }^{58}$ Although in the final moments of his course the theme of auto-affection is allowed to indicate beyond being, perhaps the most important aspect of Derrida's reading of the auto-affection of time in this course is his uncovering of a constitutive difference in Heidegger's early understanding of the temporalization of time.

The passivity Derrida finds at the basis of Dasein which was dissimulated by the privileged ecstasy of the future, is a more fundamental passivity within the movement of the temporalization of time itself. For Derrida, the point of questioning was not the figure of auto-affection as such. Rather, auto-affection will soon be seen as a minimal condition of experience itself and will be described in Of Grammatology as a "universal structure of experience." 59 The capacity for auto-affection will also soon be seen as a minimal condition of life as such. Rather, what Derrida will question in Heidegger and beyond is the interpretation of auto-affection as offering a moment of unmediated pure presence of self to self. The metaphysical promise of pure self-presence is always an obfuscation of the earlier condition of time as itself divided via a heterogeneous element. It is this more original instance of difference that opens the apparently pure continuity of the present which seemed to offer the possibility of an unmediated relation of self to self. Understanding Heidegger as articulating an alterity within time which determines the synthetic unity of ecstatic temporality can be seen as a crucial, and largely overlooked, aspect in Derrida's early reception of Heidegger's thought. However, this difference which opens within the pure auto-affection of time in his reading of Heidegger, is not to be seen in terms of the radical sense of heteronomy that Derrida will later describe as at the heart of all auto-affection.

In the difference that opens within Heidegger's auto-affection of time there is no properly heteronomous element such as space, the body, or the world. Rather, this sense of passivity and alterity remained thought solely within the alterity of time as the other to itself. Although opening a constitutive difference, it remains thought within the order of time and, like Derrida's later readings of auto-affection, also can be seen to dissimulate a deeper unthought character of time as more originally a relation of heteroaffection. However, the importance that Derrida accorded Heidegger's uncovering of a constitutive difference at the heart of temporalization is announced at the end of this course. Thinking the unity of ecstatic temporality against the background of temporalization as both auto-tradition and autoaffection locates what Derrida describes as an enigma that announces a future task: "This is the enigma that remains to be thought; this is the question that 
remains to be questioned." ${ }^{60}$ In many ways, it is this task of thinking the implications of an alterity within temporalization that can be seen to look forward to Derrida's employment of auto-affection in his reading of Husserl in Voice and Phenomenon. I turn now to Derrida's treatment of the autoaffection of time in that work in light of his earlier development of this theme in Heidegger.

\section{III.}

Derrida's seminal text Voice and Phenomenon originally appeared in 1967. The explicit theme of this work is Husserl's understanding of signs, however, in effect, this text draws into question the entire project of phenomenology as such. The focus of this deconstruction which exposes an unthought metaphysics in phenomenology is Husserl's treatment of the temporal ground of the voice. The figure of auto-affection is first employed to describe Husserl's account of the voice which seems to be an instance of pure transmission from self to self. On Derrida's reading, the unity of consciousness, the understanding of the pure presentation of phenomena in the present, is assumed by Husserl to be founded in the living voice [la vive voix]. This phenomenological voice is at once what conserves the self-identity of consciousness and which is able to reduce all aspects of difference within language. This living voice is not the sonorous physical voice, but rather, the transcendental unity of life in its full presence to itself. Derrida describes this apparently pure interiority of the voice that can speak and hear itself without having to pass through any exteriority as auto-affection: "The operation of 'hearing oneself speak' is an auto-affection of a unique kind." ${ }^{61}$ For Husserl, what makes possible this pure transmission is that it takes place within the same moment [im selben Augenblick]. The basis of this absolute self-proximity is the identity of the present. It is this purity of the present that Derrida will draw into question by once again deploying the figure of auto-affection at the heart of temporalization.

On Husserl's understanding, what guarantees the pure interiority and absolute self-proximity of the voice which hears itself is that it is held in the perfectly diaphaneous medium of the living present. Exactly because Husserl grounds the absolute self-proximity of the voice in the purely temporal core of the living present Derrida describes the concept of auto-affection as "incumbent [imposé] on us." 62 This privileging of the present, which is the basis of all temporalization in Husserl, will be shown by Derrida to actually dissimulate an earlier figure of difference within temporalization thought more originally as pure auto-affection. Derrida describes this necessity of thinking the movement of temporalization in terms of auto-affection as already articulated by Heidegger.

As soon as one takes the movement of temporalization into account, as it is already analyzed in The Phenomenology of Internal Time-Consciousness, the concept of pure auto- 
affection must be employed as well. This we know is what Heidegger does in Kant and the Problem of Metaphysics, precisely when he is concerned with the subject of time. ${ }^{63}$

Initially, this reference to Heidegger's reading of auto-affection in Kant seems to be introduced as a passing historical note. However, in light of the importance it was accorded in the Heidegger course, as a difference more original than the ecstatic temporalization of temporality in Being and Time, Derrida's reference to Heidegger can be granted a greater significance. Moreover, this drawing together of pure auto-affection and the movement of temporalization is significant in that it was exactly the movement of temporalization that Derrida announced as the point where: "phenomenology seems to us tormented, if not contested from within." ${ }^{64}$ This articulation of the movement of temporalization in terms of pure autoaffection is clearly symmetrical to Derrida's employment of Heidegger's figuration of auto-affection in his reading of Being and Time. This sense of reappropriation, perhaps one could even say of Wiederholung on Derrida's part, in which Heidegger is both proximated and then passed through, is suggested in two preceding references to Heidegger.

In his reading of Husserl's treatment of signs, Derrida points to the fact that Husserl would seem to counter the traditional subjection of sign to truth and of language to being and in fact attempts to think the ways in which signification also conditions the concepts of truth and being. However, this rejection of naïve ontology and return to life as the active constitution of truth and being through its signs is critiqued by Heidegger as simply a reversal that preserves metaphysics. In an extended footnote, Derrida describes this critique as "one of the most enduring themes of Heidegger's meditation," 65 and in response to those readings of Heidegger which would bring charges of merely another metaphysical reversal, Derrida states: "We think on the contrary, without being able to go into it here, that no one before has better escaped them." 66 However, Derrida also later clarifies: "while we appeal to Heideggerian motifs in decisive places, we would especially like to raise the question whether, with respect to [...] the pretended irreducibility of certain word unities (the unity of the word being or of other 'radical words'), Heidegger's thought does not sometimes raise the same questions as the metaphysics of presence." 67 While of course Heidegger's word nostalgia marks the hold of metaphysics on his own thought, a key instance of Derrida's appeal to Heideggerian themes at decisive places is the auto-affection of time. ${ }^{68}$

Throughout the Heidegger course as well as Voice and Phenomenon, Derrida consistently refers to the temporalization of time in Husserl as a modification of presence. Although Derrida's reference to the "im selben Augenblick" is taken from the Logical Investigations this privilege of the present is also understood to characterize the more nuanced treatments of temporalization in The Phenomenology of Internal Time-Consciousness. In this 
later text the present is seen to be continuously compounded with the nonpresence of primary memory and expectation such that it is not possible to speak of a "simple self-identity of the present." ${ }^{69}$ And yet, there remains a temporal core, a source point, which is the foundation for the movement of temporalization. This movement remains a modification ultimately internal to presence. In many ways just as the ecstatic movement of temporality in the Heidegger course was an exit still held within the ecstasis of the future. As in the Heidegger course, it is exactly this apparent temporal unity which is then thought as already constituted by a difference opened by the pure autoaffection of time. For Derrida, the source point of the moment in Husserl is already a site of time's pure auto-affection. Earlier than the seeming ability of time to ground itself in its own pure interiority, is the difference that is opened by its auto-affection: "Is not the concept of pure solitude undermined by its own origin, by the very condition of its self-presence, that is, by "time," to be conceived anew on the basis now of difference within auto-affection." ${ }^{70}$ While this difference in Heidegger's sense of auto-affection was still internal to a temporal or ontological determination, for Derrida, it will open upon a difference already in excess of these orders.

Derrida's employment of Heidegger's thought of the auto-affection of time in his reading of Being and Time, clearly looks forward to the way autoaffection is also applied to Husserl's account of temporalization in Voice and Phenomenon. In both texts, Heidegger's thought of auto-affection functions as a first articulation of an internal difference within the seeming continuity of time. This can be seen in both the temporalization of time from out of the future in Being and Time and on the basis of the present in The Phenomenology of Internal Time-Consciousness. In both works, Derrida locates Heidegger's thought of auto-affection as the initial articulation of an earlier alterity opening within time itself. From this perspective, Heidegger's thought can be seen to also gesture towards an initial destabilization of the programs of phenomenology in both texts. However, while Heidegger's sense of difference was thought only within the scope of time and being, the difference which opens within auto-affection in Voice and Phenomena of course overflows that initial Heideggerian figuration of alterity. As is well known, what it opened onto was a hetero-affection at the heart of "time" which was dissimulated by every assurance of pure auto-affection and approached solely in Derrida's own thought of différance. 
${ }^{1}$ Jacques Derrida, Heidegger: la question de l'Être et l'Histoire Cours de l'ENS-Ulm 1964-65 (Paris: Galilée, 2013), 296.

${ }^{2}$ See Dominique Janicaud, “Jacques Derrida Interviews of July 1 and November, 1999” in Heidegger in France, trans. François Raffoul and David Pettigrew (Bloomington: Indiana University Press, 2015), 337-363. Jacques Derrida, Positions, trans. Alan Bass (Chicago: The University of Chicago Press, 1981), 9-14 ; 47-55.

3 Jacques Derrida, Heidegger: The Question of Being and History, trans. Geoffrey Bennington (Chicago: The University of Chicago Press, 2016).

${ }^{4}$ Although Heidegger's ontological difference was seen as still in the grasp of metaphysics, the proximity that Derrida accorded crossing out and passing through Heidegger in relation to his own thought in 1967 is unparalleled. For indications of this relation, see Jacques Derrida, Margins of Philosophy, trans. Alan Bass (Chicago: The University of Chicago Press, 1982), 22. Jacques Derrida, Of Grammatology, trans. Gayatri Spivak (Baltimore: Johns Hopkins University Press, 1997), 23. This proximity is also expressed in terms of time when Derrida describes the relation between his understanding of temporization and Heidegger's sense of temporalization in Being and Time as a "strict communication." Derrida, Margins of Philosophy, 10.

${ }^{5}$ Derrida confirms this in an interview and lists Heidegger's Kantbuch as the topic of an entire course: "Then, I became an assistant at the Sorbonne from 1960-64, and I gave entire courses on Heidegger: on Kant and the Problem of Metaphysics, and on 'Irony, Doubt and the Question.' It is probably during those years as an assistant that I read Heidegger most continuously, and most systematically, while referring to him." Dominique Janicaud, “Jacques Derrida Interviews of July 1 and November, 1999," 342.

${ }^{6}$ See Michael Naas, “Violence and Historicity: Derrida's Early Readings of Heidegger," Research in Phenomenology, vol. 45 (2015): 191-213. David Farrell Krell, “History, Natality, Ecstasy: Derrida's First Seminar on Heidegger, 1964-1965," Research in Phenomenology, vol. 46 (2016): 3-34.

${ }^{7}$ It is difficult to overestimate the significance of this term, as Lenonard Lawlor aptly states: "Indeed, it is possible to say without exaggeration that every deconstruction Derrida has ever written targets auto-affection. Deconstruction aims to show that all auto-affection, however, it is conceived, is really and fundamentally heteroaffection." Lenonard Lawlor, “Auto-Affection” in Jacques Derrida: Key Concepts, ed. Claire Colebrook (New York: Routledge, 2015), 130. Catherine Malabou confirms this assessment: "Derrida's thought may be regarded, as a whole, as a long and continuous 
deconstructing gesture of autoaffection in the name of heteroaffection." Adrian Johnston and Catherine Malabou, Self and Emotional Life (New York: Columbia University Press, 2013), 19.

8 This is announced in Of Grammatology: "the movement of temporalization and the schematism of imagination, pure sensibility and the auto-affection of the present by itself, all that Heidegger's reading has strongly repeated in Kant and the Problem of Metaphysics" Derrida, Of Grammatology, 342 note 21. Derrida will later return to this text as a key reference in his later treatments of auto-affection which, as he states in "To Speculate - on 'Freud" must be understood as: "related to the auto-affective structure of time ... such as it is described ... in Heidegger's Kantbuch." Jacques Derrida, "To Speculate - on "Freud" in The Postcard: From Socrates to Freud and Beyond, trans. Alan Bass (Chicago: University of Chicago Press, 1987), 359.

${ }^{9}$ Derrida, Margins of Philosophy, 31 note 3 . In that same text he also quotes a passage on Heidegger's treatment of the pure intuition of time in section 32 of Kant and the Problem of Metaphysics that, as Derrida describes: "clarifies all the concepts of Sein und Zeit" (50, note 29).

${ }^{10}$ Derrida, Heidegger: The Question of Being and History, 182.

11 Martin Heidegger, Logic: the Question of Truth, trans. Thomas Sheehan (Bloomington: Indiana University Press, 2010). See especially: “\$28. Time as original pure self-affection."

12 Heidegger, Logic: the Question of Truth, 280.

13 Derrida, Margins of Philosophy, 31 note 3.

14 The importance of auto-affection in Derrida's reception of Being and Time is indicated by later key references: "Dasein affects itself with this movement [the intervallic movement of Erstreckung] and this auto-affection belongs to the ontological structure of its historicality." Jacques Derrida, "Geschlecht I: Sexual Difference, Ontological Difference" in Psyche Inventions of the Other vol. II ed. Peggy Kamuf and Elizabeth Rottenberg (Stanford: Stanford University Press, 2008), 20.

15 Derrida, Heidegger: The Question of Being and History, 169.

${ }^{16}$ Derrida, Heidegger: The Question of Being and History, 169.

${ }^{17}$ Derrida, Heidegger: The Question of Being and History, 169.

18 Derrida, Heidegger: The Question of Being and History, 23.

${ }^{19}$ Derrida, Heidegger: The Question of Being and History, 85.

${ }^{20}$ Derrida, Heidegger: The Question of Being and History, 85.

${ }^{21}$ Derrida, Heidegger: The Question of Being and History, 86.

${ }^{22}$ Derrida, Heidegger: The Question of Being and History, 92.

${ }^{23}$ Derrida, Heidegger: The Question of Being and History, 97. 
${ }^{24}$ This sense of "running out of breath" which appears many times in Derrida's course should not be taken as a prosaic turn of phrase, but rather, perhaps as invoking the metaphorics for being in terms of breath that Derrida referred to in, for example, "Violence and Metaphysics" in the works of Renan, Nietzsche and Descartes and also again in Nietzsche earlier in this course. Cf. Derrida, Writing and Difference, trans. Alan Bass (Chicago: University of Chicago Press, 1978), 139 and Heidegger: The Question of Being and History, 70.

${ }^{25}$ Derrida, Heidegger: The Question of Being and History, 137.

${ }^{26}$ Derrida, Heidegger: The Question of Being and History, 148.

${ }^{27}$ Derrida, Heidegger: The Question of Being and History, 188.

${ }^{28}$ Derrida, Heidegger: The Question of Being and History, 174.

${ }^{29}$ Derrida, Heidegger: The Question of Being and History, 173.

${ }^{30}$ Derrida, Heidegger: The Question of Being and History, 174.

${ }^{31}$ Derrida, Heidegger: The Question of Being and History, 168.

32 Derrida, Heidegger: The Question of Being and History, 169.

${ }^{33}$ Derrida, Heidegger: The Question of Being and History, 169.

${ }^{34}$ Derrida, Heidegger: The Question of Being and History, 134.

35 Martin Heidegger, Kant and the Problem of Metaphysics, trans. Richard Taft (Bloomington: Indiana University Press, 1997), 122.

${ }^{36}$ Heidegger, Kant and the Problem of Metaphysics, 133.

${ }^{37}$ Derrida's account of the degree to which Heidegger allowed the thought of autoaffection in his repetition of Kant to proximate his own understanding of temporality in this period is clearly supported by Heidegger's text: "The pure inner sense is pure self-affection, i.e., original time [ursprüngliche Zeit]." Heidegger, Kant and the Problem of Metaphysics, 138.

${ }^{38}$ Derrida, Heidegger: The Question of Being and History, 176.

${ }^{39}$ Derrida, Heidegger: The Question of Being and History, 176.

${ }^{40}$ Derrida, Heidegger: The Question of Being and History, 181.

${ }^{41}$ Derrida, Heidegger: The Question of Being and History, 180.

42 Derrida, Heidegger: The Question of Being and History, 180.

${ }^{43}$ Derrida, Heidegger: The Question of Being and History, 185.

${ }^{44}$ Derrida, Heidegger: The Question of Being and History, 202.

${ }^{45}$ Derrida, Heidegger: The Question of Being and History, 180.

${ }^{46}$ Derrida, Heidegger: The Question of Being and History, 12, 30, 94, 179.

${ }^{47}$ Derrida, Heidegger: The Question of Being and History, 180.

${ }^{48}$ Derrida, Heidegger: The Question of Being and History, 181. 
49 Michel Henry, The Essence of Manifestation, trans. Gerard Etzkorn (The Hague: Martinus Nijhoff, 1973).

${ }^{50}$ Derrida, Heidegger: The Question of Being and History, 181.

${ }^{51}$ Derrida, Heidegger: The Question of Being and History, 181.

52 Derrida, Heidegger: The Question of Being and History, 184.

${ }^{53}$ Derrida, Heidegger: The Question of Being and History, 184.

${ }^{54}$ Derrida, Heidegger: The Question of Being and History, 185.

${ }^{55}$ Derrida, Heidegger: The Question of Being and History, 205. Heidegger: la question de l'Être et l'Histoire, 299.

${ }^{56}$ Derrida, Heidegger: The Question of Being and History, 224.

${ }^{57}$ Derrida, Heidegger: The Question of Being and History, 224.

${ }^{58}$ Cf. Derrida, Of Grammatology, 23 and Margins of Philosophy, 22.

${ }^{59}$ Derrida, Of Grammatology, 165.

${ }^{60}$ Derrida, Heidegger: The Question of Being and History, 204.

61 Jacques Derrida, Speech and Phenomena, trans. David B. Allison (Evanston: Northwestern University Press, 1973), 78.

62 Derrida, Speech and Phenomena, 83.

${ }^{63}$ Derrida, Speech and Phenomena, 83.

${ }^{64}$ Derrida, Speech and Phenomena, 6.

${ }^{65}$ Derrida, Speech and Phenomena, 25, footnote 5.

66 Derrida, Speech and Phenomena, 26, footnote 5.

${ }^{67}$ Derrida, Speech and Phenomena, 74, footnote 4.

${ }^{68}$ Another Heideggerian element in this text which is only now visible in light of the earlier Heidegger course is Derrida's reference to ontic metaphor [la métaphore ontique] which was a central theme developed in that course. Cf. Derrida, Speech and Phenomena, 85.

${ }^{69}$ Derrida, Speech and Phenomena, 63.

${ }^{70}$ Derrida, Speech and Phenomena, 68. 